\title{
Governing 'disadvantage' through funded early years places and reconfigured spaces
}

\author{
Siew Fung Lee, Orcid iD 0000-0001-5733-2581
}

UCL Institute of Education, UK

\begin{abstract}
This article examines how the policy of funded early years places for 'disadvantaged' 2-year-olds (FNP) in England reconfigures spaces within early childhood and care (ECEC) in new ways of working with young children. Using practitioners' interview data from early years settings in London, this article uses Foucauldian technologies of governmentality to shed light on how FNP responds to the problem of 'disadvantage' as new mobile modes of governance. The paper explores how practitioners reconfigure their established spaces to incorporate provision and practice suitable for 2-year-olds and the challenges practitioners face in implementing the policy. The analysis considers 'space as assemblage' by focusing on three key themes: dividing spaces through split rationality, dividing practices through othering and the reconfiguration of established ways of working. The themes trace how policy-driven technologies re-interpret ECEC in narrow and alternative ways by making a set of practices possible, engendering new pedagogical relationships. This article highlights the complex conditions of (im)possibility for 'doing' ECEC under austerity. When viewed in the broader context, policy reforms are increasingly reaching into ECEC as strategic spaces for new modes of governing, sustained by a global agenda in neoliberal education reforms.
\end{abstract}

\section{Introduction}

Early childhood education and care (ECEC) is increasingly positioned by policy as strategic spaces for economic and social norms in 'disadvantage' and optimising 'human capital' driven by a global regime of neoliberalism. In England, funded early years places for 'disadvantaged' 2-year-old children (FNP) were introduced in September 2013, which aimed to improve educational outcomes, narrow the attainment gap and encourage parental employment. Using the Foucauldian approach, this article examines how FNP govern 'disadvantage' by using technologies of governmentality which are productive of new modes of governance. The article draws on empirical research to consider how early years practitioners reconfigure their established spaces in incorporating provision suitable for 2year-old children and the challenges practitioners face in implementing the policy. The article uses Ong's (2007, p. 5) 'space of assemblage' as an analytical tool, first, to highlight how FNP binds with situated sets of elements and rationalities. Second, to trace how FNP reassemble established practices into new configurations of working and being with young children in ECEC under austerity. These processes are illustrated on a case-by-case basis, to reveal how FNP govern through strategic dividing practices and a particular regime of developmentality. This article uses interview data and materials from doctoral research of ECEC case-study settings in London that took place from January 2016 to June 2017. 
Terminology in referencing ECEC vary across early years policies, primarily regarding FNP as 'childcare'. Table 1 presents a sample of policies of direct relevance to both FNP and 'disadvantage' and traces how policy contexts discursively construct different terms when referring to ECEC provision. Confusingly, the terminology is used interchangeably and seems to vary across the country. Within the case studies, the participants use terms such as 'free nursery places', 'free offer', and '2year provision'.

\begin{tabular}{|l|l|l|l|l|l|l|l|l|}
\hline & $\begin{array}{l}\text { National } \\
\text { Childcare } \\
\text { Strategy } \\
\text { (DfEE, } \\
\text { 1998) }\end{array}$ & $\begin{array}{l}\text { National } \\
\text { Service } \\
\text { Framework } \\
(\mathrm{DH}, 2004)\end{array}$ & $\begin{array}{l}\text { Choice } \\
\text { For } \\
\text { Parents } \\
\text { (DfES, } \\
2004)\end{array}$ & $\begin{array}{l}\text { The } \\
\text { Children's } \\
\text { Plan } \\
\text { (DCSF, } \\
\text { 2007) }\end{array}$ & $\begin{array}{l}\text { Next } \\
\text { Steps for } \\
\text { Early } \\
\text { Learning } \\
\text { and } \\
\text { Childcare } \\
\text { (DCSF, } \\
2009)\end{array}$ & $\begin{array}{l}\text { Supporting } \\
\text { Families in } \\
\text { the } \\
\text { Foundation } \\
\text { Years (DH, } \\
2011)\end{array}$ & $\begin{array}{l}\text { More } \\
\text { Great } \\
\text { Childcare } \\
\text { (DfE, } \\
2013 b)\end{array}$ & $\begin{array}{l}\text { More } \\
\text { Affordable } \\
\text { Childcare } \\
\text { (DfE, } \\
2013 a)\end{array}$ \\
\hline Childcare & 527 & 9 & 697 & 42 & 458 & 76 & 73 & 302 \\
\hline $\begin{array}{l}\text { Early (years) } \\
\text { education }\end{array}$ & 21 & 2 & 66 & 11 & 0 & 92 & 46 & 54 \\
\hline $\begin{array}{l}\text { Education and } \\
\text { care }\end{array}$ & 3 & 0 & 1 & 0 & 0 & 0 & 10 & 0 \\
\hline $\begin{array}{l}\text { Free (early) } \\
\text { education }\end{array}$ & 5 & 0 & 8 & 6 & 0 & 25 & 1 & 0 \\
\hline $\begin{array}{l}\text { Free education } \\
\text { and childcare }\end{array}$ & 0 & 0 & 15 & 4 & 0 & 0 & 0 & 0 \\
\hline $\begin{array}{l}\text { Free (early } \\
\text { years) } \\
\text { entitlement }\end{array}$ & 0 & 0 & 19 & 3 & 27 & 30 & 0 & 1 \\
\hline Funded, funding & 40 & 13 & 18 & 50 & 73 & 33 & 13 & 47 \\
\hline
\end{tabular}

Table 1: Terminology of early years provision and frequency of use in the sample ECEC policies

The Department for Education (DfE) uses terms such as 'funded early education' and 'free education and childcare' on their website. Thus, for consistency in the context of this study, 'funded nursery places for 2-years-olds' are used and abbreviated as FNP. To be clear, various early years and childcare providers, including registered childminders, offer funded places for 'disadvantaged' 2-yearolds.

\section{Setting the context}

My interest in this study stems from my work as an early years practitioner for 20 years. I work with 2 to 4-year-old children and have implemented rapid ECEC policy reforms, starting with the Curriculum Guidance for the Foundation Stage (CGFS) (QCA, 2000) for 3-5 year-olds, which set out Early Learning Goals in six areas of learning. This was followed by Birth to Three Matters (BTM) (DfES, 2002), then the Early Years Foundation Stage (EYFS) (DfES, 2007) which brought together CGFS and BTM. Further versions of the EYFS followed in 2012, 2014 and 2017 (DfE, 2017), along with 
revisions to assessments and checks. Over the years, I opted for younger age groups (2-3-year-olds) to escape the creep of assessments and the culture of performativity. As Osgood (2006b) notes:

As a consequence of the National Childcare Strategy introduced in 1998, early childhood education and care providers have experienced increasing steerage from the state. Like school teachers, early years practitioners now have to wrestle with the demands for accountability, attainment targets, a compulsory early years curriculum and standardised approaches to their practice. (p. 188)

This article responds to an urgent need for critical policy methodologies which are specific to ECEC in problematising how power effects infuse 'education via macro-level socio-political and economic contexts, and how that power then infuses micro-level practices and relationships' (Wood, 2017, p. 109). There is international educational research on critical policy approaches engaged in Foucauldian thinking specific to children under five in nurseries. For instance, Moss's (2014b, 2017) study contested and resisted neoliberal discourses in quality and high returns, and markets. His critical examination of ECEC policy from 1997 - 2013 (Moss, 2014a, p. 356) argued that policy developments since 1997 had been a case of missed opportunity, in favour of resurgent neoliberal faith in extreme marketisation and 'the unqualified superiority of private provision'. Mac Naughton's (2005) critical poststructuralist approach to action research in early childhood studies and practice focused on the Foucauldian approach to thinking differently about ECEC. Osgood's (2006a, 2010, 2012) extensive in-depth ethnographic examination of professional identities in early childhood includes policy genealogy to trace discursive construction of identities through discourses of gender, sexuality, 'race' and class. Other critical genealogical research on early years policy focuses on 'network ethnography' in discourses of 'quality' (Hunkin, 2016) and governing constructs of 'disadvantage' (Lee, 2019).

ECEC research for children under three tended towards evaluating and building on dimensions of 'high quality' provision and 'best practice'. Notably, Mathers et al. (2014) carried out a policy and practice review of FNP, which focused on evidence-based reviews and evaluations of 'quality' provision and practice for children under three. Georgeson et al.'s (2014) study explored 'high-quality provision' and 'good practice' for 2-year-olds from the perspective of practitioners. Other research focused on the piloting of FNP (Smith et al., 2009); an implementation study for local authorities and providers (Gibb et al., 2011); the take-up of ECEC provision by families with different dimensions of 'disadvantage' and barriers experienced by 'disadvantaged' families (Speight et al., 2010). An eight- 
year longitudinal Study of Early Education and Development (SEED) commissioned by the DfE following approximately 6,000 children across England from age two to the end of Key Stage 1. SEED's latest reports were on 'quality' and 'potential value for money' in early education', thereby reflecting the dominant policy drivers of economic and educational effectiveness. In England, the effects of increased formalisation of early experiences for 2-year-old children framed from the perspective of 'disadvantage', and the influence of policy on practice in a specific context have rarely been discussed. There is little research on the impact of FNP on the subjective experiences of 'disadvantaged' 2-year-olds and practitioners in ECEC settings - perhaps subsumed by the broader concerns of the dominance of assessments as well as school-readiness debates. This article aims to contribute to the critical analysis of policy and practice specific to the provision of funded places for 2year-old children and how the power effects of policy impact on practitioners and children.

Since the 1980s global education policy reforms in different countries follow similar patterns framed as 'evidence-based policy agenda' what Sahlberg (2011, p. 175) calls the 'Global Education Reform Movement' (GERM) rooted in neoliberal thinking of market-like competition, increased school choice, increased governance of educators and accountability. GERM has gained global popularity, visibly in the standardisation of educational and pedagogical processes (Sahlberg, 2011, p. 179) now extended to spaces for children under compulsory school age. These processes are evident in England, in the piloting of the Reception Baseline Assessment (2020) and consultation to further reforms in the Early Years Foundation Stage 2021ii designed to improve readiness and alignment with compulsory schooling. Across countries, the Organisation for Economic Co-operation and Development's controversial International Early Learning and Child Well-Being Study (IELS) generates ongoing concerns over intensified performativity and school-readiness demands on young children. The IELS draws 'early childhood into a global standardised assessment framework that is unable (unwilling!) to see children's experiences in the education system through any other lens than the provided by PISA [Programme for International Student Assessment]' (Moss \& Urban, 2017; Urban, 2017, p. 20).

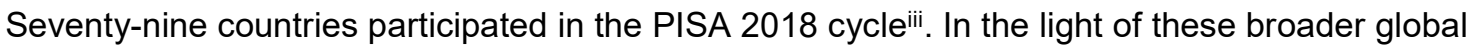
developments in ECEC, this article regards the introduction of FNP provision as a reaching effect of the GERM agenda into pre-school spaces in formalising early learning experiences, in particular for disadvantaged children. 
FNP was first introduced in England in Choice for parents, the best start for children (DfES, 2004) as a pilot to 'extend the benefits of high-quality early education and childcare to younger children for 12,000 two-year-olds living in disadvantaged areas' (DfES, 2004, p. 24). The places were increased to $40 \%$ of the 'most disadvantaged children' from September 2014 (DfE, 2013a). In 2006, 32 local authorities offered 13,500 places from 7.5 to 12.5 hours per week for 38 weeks. Each local authority could choose how it implemented the scheme and targeted a range of different types of families (Maisey et al., 2013). After the initial roll-out, an additional 32 local authorities were funded in 2008 , increasing provision to 15 hours per week (DCSF, 2009). Later, as part of the Coalition's Fairness Premium (2010), $20 \%$ of the 'most disadvantaged' children (130,000 places) became eligible for 15 hours per week for 38 weeks from September 2013, increasing to 40\% from September 2014 onwards (DfE 2013a). The eligibility criteria are means-tested based mainly on income and Department for Work and Pensions benefits, and as such, constitute new objectivity that is productive of new economic and social norms. A means-tested provision is seen as likely to be more effective and efficient in bringing 'disadvantaged' subjects for targeted intervention. This form of provision embodies the sorting of populations into a particular category of 'disadvantage' for differential treatment - in effect, 'disadvantaged' 2-year-olds are constructed as a 'problem of the population' (Foucault, 2009). The term 'disadvantage' implies that economically poor children are disadvantaged by their backgrounds what Field (2010: 22) calls 'class-based differences'. In this regard, the idea behind FNP is to prepare 2-year-olds for nursery when they turn three. This move constitutes a form of nursery readiness, which includes self-care and a 'list of essential skills' (Field, 2010, p. 22). Within this context, childcare has moved up the policy agenda as the neoliberal answer mobilised 'to break the cycle of disadvantage ... improve children's education outcomes ... support parental employment' (DfES, 2004, p. 5), in particular under austerity economics (Lewis \& West, 2017; Lloyd \& Penn, 2014). The next section sets out the analytical tools used in examining how policy technologies productively render early years settings as economic and political spaces.

\section{Governmentality: technologies in the 'conduct of conduct'}

Foucault introduced the concept of 'governmentality' in the 1970s in the course of his investigations into strategic political power. Instead of taking on a macro view of the state that centres on power 
holders, the approach investigates 'the microphysics of power and anonymous strategies' (Lemke, 2002, p. 51). Importantly, Foucault's relational concept of power is about connective configurations or networks that are interactional, mobile and flexible, as opposed to power as a stable and fixed entity that could be 'stored' at particular institutional sites (Lemke, 2012, p. 35). The article does not evaluate FNP as a stable and standardised apparatus in terms of policy as outcome, for example, its policy objectives, its effectiveness nor is it evaluating 'best practice' in settings for 'disadvantaged' 2-yearolds. The analysis uses problematisation as a heuristic way to open a discursive space in which to question the processes of policy and to examine particular 'realities' and problems. Problematization offers new analytical possibilities to productively consider how specific concepts such as 'disadvantage' are rendered usable and useful for policy. Ong's (2007, p. 5) concept of 'space as assemblage' is used to examine how FNP, in the form of mobile technology of government, interacts with situated practices and rationalities in reconfiguring new ways of working and being with young children. For this article, the term 'assemblage' frames a space of inquiry to take into account the entanglement of rationalities and technologies within a situated interplay of different interests and ways of doing things.

Gordon (1991, p. 3) distinguishes between 'government' as an activity or practice, 'arts of government' as 'knowing what that activity consisted in, and how it might be carried out', and 'governmentality' as a form of rationality in 'thinking about the nature of the practice of government ... capable of making some form of that activity thinkable and practicable both to its practitioners and to those upon whom it is practised'. This point is also taken up by Lemke (2001, p. 191) who suggests that the 'semantic linking of governing ('gouverner') and modes of thought ('mentalité') indicate that it is not possible to study the technologies of power without an analysis of the political rationality underpinning them'. Foucault's inconsistent approach to the terms 'government' and 'governmentality' tends to change over time in that 'each formulation contains a modification, a transformation' (Dean, 2010, p. 13). For instance,

Foucault corrects the findings of the earlier studies in which he investigated subjectivity primarily with a view to 'docile bodies' and had too strongly stressed processes of discipline. Now the notion of government is used to investigate the relations between technologies of the self and technologies of domination (Foucault, 1988). (Lemke, 2002, p. 52) 
This formulation of governmentality brings into play technologies of government with technologies of the self and affords contact points between the government of the state and self-regulation. The analysis here is concerned with a particular dimension of 'technology' that seeks 'to shape, normalise and instrumentalise the conduct, thought, decisions and aspirations of others in order to achieve the objectives they consider desirable' (Miller \& Rose, 1990, p. 8).

The term 'technology' refers to everyday and mundane activities, not so much a totalising political schema or some hidden or covert purpose; it investigates how policy technologies constitute and legitimise a particular mode of governing. In this regard, this article does not claim to provide a sociological and ethnographic description (truths) of provision nor the actual mechanisms of governance. Instead, a mode of governing is about steering and searching for forms of self-regulation in leading and controlling the 'conduct of conduct' of subjects. Foucault (1982, p. 790) makes a point with 'conduct' in that 'governmentality' did not refer only to 'political structures and the management of states', it also includes how 'the conduct of individuals or groups might be directed'. In the context of the study reported in the following section, this particular notion of government is useful in highlighting different rationalities that render a particular 'disadvantage-space' amenable to certain kinds of actions. Foucault (1982, p. 779) warns against a generalised or totalising view of governmentality: 'the word 'rationalisation' is dangerous. What we have to do is analyse specific rationalities rather than always invoke the progress of rationalisation in general'. The analysis here articulates a formation of mutually constitutive interactions between policy-driven technologies and situated practices within a specific space through which problems are solved (Ong, 2006, p. 9). Technologies always change and adapt to a 'newly identified problem or solution while retaining certain styles of thought and technological preferences' (Rose et al. 2006, p. 98).

While I rely on a technological approach as a heuristic device to help identify modes of governing, I apply with deterministic caution that 'just because a technology has potential use, [such as that of normalisation], it does not imply that this is the use to which it will be put' (Rose, 1999b, p. 244). Here, the contextual analysis focuses on how early years practitioners, who are experienced in ways of working with 3 to 4 year-olds, reconfigure space and practice in their settings in order to implement funded places for 2-year-olds. This process is what Rose (1999b, p. 235) calls 'the emergence of new possibilities and the complexification of the old'. In their study on policy enactments in secondary 
schools, Ball et al. (2012, p. 41) emphasise the need for context-bound critical perspectives in policy work as 'policy-making and policymakers tend to assume 'best possible' environments for 'implementation': ideal buildings, students and teachers and even resources'.

\section{Methodology}

This article draws on data from an ethnographic study of FNP in London of two children's centres (CC1 and CC2), and a state-maintained nursery school (NS1) over 18 months, from January 2016 to July 2017. I purposively selected three settings within the same borough based on whether they offered FNP, rather than their representativeness of early years setting. The study focused on children's and practitioners' everyday experiences of implementing FNP. CC1 and CC2 introduced their offer in September 2013; CC1 had 12-morning and 12-afternoon places, and CC2 had 33morning places and 22-afternoon places. NS1 offered FNP in September 2014 with 12-morning places. Based on the proportion of children of students on Free School Meals (FSM) in the local area as an indication of poverty, the FSM percentages in all three settings were about three times the national average of $14.1 \%$ in $2017^{\text {iv }}$. The settings were located in areas within the top $10 \%$ of Income Deprivation Affecting Children Index (IDACI); IDACI measured the proportion of all children aged birth to 15 living in income-deprived families in England. CC1 was in a ward where nearly $60 \%$ of children were in the top 5\% of England's deprivation index. Both CC1 and NS1 were rated as 'outstanding' and CC2 as 'good' in terms of The Office for Standards in Education, Children's Services and Skills (Ofsted) inspection framework.

I collected data as a participant-observer which enabled me to work alongside practitioners and to observe their everyday practices with children and adults while maintaining the flexibility to engage informally with participants. I helped set up and tidy away resources, participated in story-time, music sessions, football, pitched in with children's snacks and lunches, day trips, forest school trips, and wrote brief observations of children for their records. All three settings had indoors and outdoors areas, and a 'free-flow' curriculum in the sense that children were 'free' to access and choose their preferred areas of learning during sessions. I spent two terms in each setting, spending three or four days per week, either in morning sessions (8.30 am to $11.45 \mathrm{am})$ or in afternoon sessions $(12.45 \mathrm{pm}$ 
to $5 \mathrm{pm}$ ), and sometimes full-day sessions ( $8.30 \mathrm{am}$ to $5 \mathrm{pm}$ ) to observe weekly planning at the end of the day. Four types of data were collected: handwritten field notes, semi-structured interviews, sample documents, and photographs. The research generated a set of 48 interviews with 32 practitioners, of which 26 were nursery staff, 4 were deputy managers, and 2 were headteachers. All participants and settings used pseudonyms; all participants were referred to as codes, for example, $\mathrm{H} 1$, to help anonymise data. The research was conducted with ethical approval from my university following the guidelines of the British Education Research Association.

Braun and Clarke's (2006, p. 79) approach in the thematic analysis systematically identified, analysed and reported patterns (themes) within data. Following Foucault, the theory-driven coding prioritised 'how' questions in which, 'governmentality is about how to govern' (Gordon, 1991, p. 7). The process of analysis was iterative and involved continual dialogue between theory and data, transcribing interviews and field notes, frequent reading and re-reading of transcripts, and systematically working and thinking with Foucault's ideas. Foucault's power lens was used to interpret participants' subjective and contextual experiences of FNP. To date, research that foreground contexts are little considered in education policy (Ball et al., 2012). These contextual dimensions include diverse external backgrounds, specific and situated elements within settings which constrain, pressure, and enable policy enactment, tend to be neglected in policy-making and research. The case studies were not intended to generalise findings or to make claims about how all children and adults experience FNP; instead, understand how participants in their particular contexts experienced and perceived their practice. The article is organised around three interrelated themes using Ong's (2007, p. 5) 'space as assemblage' to explore technology of governmentality in governing 'disadvantage': dividing spaces through split rationalities, dividing practices through othering and reconfiguring established ways of working.

\section{Dividing spaces through split rationality}

The themes arising from the data analysis are based on practitioners' experiences of working with children of different ages specific to organising routines and spaces across the settings. Although the views are 'described in distinct terms, this should not suggest the absence of variation and subtle differences ... and should not imply that any one of them should be universalised to the exclusion of 
the others' (Giroux, 2001, p. 176). Rather, the data suggest practitioners have their particular relationships to situated modes of thought as the following extract demonstrates:

I'm hearing just one part of my point of view, my perspective. I may have a colleague that may have a completely different sense. And I think 'gosh we're both working in the same place but it ... clearly that we've got some differences, which is good'. I hope that the principles for everybody are the same and I think we've worked long enough here to know that. But yes, of course, we have to have different perspectives on things. (SW, CC1)

Rose et al.'s (2006, p. 84) specific analysis of governmentality in terms of modes of thought draws attention to how situated technologies respond and adapt to new problems or solutions 'while retaining certain styles of thought and technological preferences'. These situated techniques can be observed through dividing practices which organise an analytical space through processes of classification which work to limit, exclude or include possibilities of being. In what follows, I provide a brief outline of how the case studies organised FNP in their settings. CC1 and NS1 organised key groups for 2-yearolds with separate key groups for 3 - 4-year-olds, while CC2's key groups consisted of 2 - 4-years-olds in terms of a range of mixed ages within the individual key groups. CC1 and NS1 operated on a freeflow mixed-age plan and have designated FNP rooms for younger children in the form of a 'familiar base'. CC2 opted for an integrated free approach for all 2 to 4 year-olds throughout their nursery, loosely designating a smaller room to settle 2 -year-olds. 2 year-olds make up $40 \%$ ( 33 children) of their morning registered places.

Practitioners in NS1 express different individual pedagogical preferences with children's ages: 'l've had staff tell me, I don't like, you know, looking after little ones. I'm glad I'm out of that room' (M1, NS1). Whereas his colleague comments, 'I don't know why that being with the 2-year-olds is not as important as being with the older children, it doesn't make any sense to me because surely they can see that the work that we put in with the 2-year-olds' (M2, NS1). Most of CC2's practitioners prefer separate spaces to age groups: a split system for 2-year-olds and 3 to 4 -year-olds. Practitioners refer to FNP as 'free nursery places', 'free offer', '2-year provision' and 'childcare' for 2-year-olds, they regard the main nursery as 'early education' for 3 to 4 -year-olds. This position is evident in practitioners' responses in terms of organising their children based on their age groups:

Well, life would be easier if they were two separate groups, to be honest ... we'll do a much better job of supporting both groups, and we will find a way to make it work as best we can. But I think in an ideal 
situation, you wouldn't have the two groups together or certainly not for the whole day, as they are. (H7, CC2)

To some extent, the practitioners' comments re-enact and reinforce the dominant split in both government and public psyches, between 'childcare' as care services and 'early education' for 3 to 4 year-olds as a public good for which there is a universal entitlement. The split thinking materially reflects different services, systems of funding, and segmented workforces. Hence, 'early education' happens mainly in nurseries, the remainder being 'childcare' regarded as 'a private commodity to be purchased by parent-consumers in a private market where suppliers are mostly for-profit providers (Moss, 2010, p. 184). Different systems of funding take precedence in the ECEC sector:

\footnotetext{
Even as 'early education' expanded, it remained wholly funded by the state, through direct grants to providers. In contrast, 'childcare' continued to rely mainly on parental fees, though mitigated by the introduction of childcare tax credits, a development of the demand-side subsidy approach that the Conservative government had first introduced [in 1994 through early education vouchers]. (Moss, 2014a, p. 348)
}

Data from the DfE's funded early years education suggests market-led for-profit providers have the more significant share of 2 - and 3-year-olds ( $86 \%$ and $65 \%$, respectively) and $22 \%$ of 4 -year-olds (DfE, 2019). The majority of 4-year-olds access their universal entitlement in Reception classes (the last year of the EYFS) in primary schools.

\section{Dividing practices through othering}

The practitioners' rationality in ages and stages reflect what Mac Naughton (2005) and Dahlberg et al. (2007) argue as the pervasive influence of developmental psychology on early childhood educators and other professionals who work with young children, specifically their pedagogies and provision. Here, forms of knowledge and expertise are deployed as developmental truths that facilitate, enhance and maximise children's 'normal' or 'typical' development. According to Mac Naughton (2005, p. 29), 'truths of the normal child matter because we use them as we construct relationships and institutions around what we see as the normal child, the abnormal child, and the delayed child' and within this context, the image of 'the disadvantaged child'. Professional training, governmental policies (DfES, 2004, 2007; DH, 2011) and the curriculum of the EYFS (DfE, 2017) are productive of technology of 
normalisation. Drawing on Fendler's (2001) idea of 'developmentality', normalising technology constitutes and sets in motion self-regulating practitioners who can conduct their selves in the process of 'governing without governing' (Rose, 1993, p. 298):

I call this technology developmentality as a way of alluding to Foucault's governmentality and focusing on the self-governing effects of developmental discourse in curriculum debates. 'Developmentality', like 'governmentality' describes a current pattern of power in which the self disciplines the self. (Fendler, 2001, p. 120)

Thus, a particular regime of developmentality governs the conduct of practitioners within a powerful EYFS framework. This regime, in turn, is reinforced through the health and development review at 2436 months, and the EYFS Profile in which children are expected to achieve a 'Good Level of Development' as measured by their achievement of the Early Learning Goals at age five. Notions of normality, which dominate early years policies, involve 'a valuation of scientific truth and expert authority' in terms of expectations and outcomes to be achieved (Rose, 1999a, p. 133). It is argued that techniques of othering emerge from power-knowledge relations which permit and legitimate normal ways of thinking. This constitutes the starting point for most classifications and ability groupings that continue into formal schooling, as Dunne (2009, p. 50) suggests, 'the normality against which the other categories are constructed, and against which the 'others' become visible'. For example, practitioners spoke of younger children's needs in terms of 'naps and nappies', 'toilet-trained' and 'not toilet-trained'; 'disruptive' and 'creative play'; and different settling-in routines. The othering of care with attitudes to nappy-changing creates tension between practitioners' beliefs framed within positive key person relationships, described as 'sensitive and responsive to the child's needs, feelings and interests' (Education, 2012, p. 2) and policy expectations (norms). Children who are not toilettrained are othered as 'not ready' and thus, spatially othered from 3-4-year-olds' spaces in the main nursery. FNP practitioners are othered from 3-4-year-old practitioners (particularly in CC2) from split rationality of early education and childcare, as this excerpt shows:

It got very cliquey - in that those staff wouldn't work with any other children, it was 'whose child is this?' 'Where's the key person?' Ridiculous, it got really silly. And it wasn't as free flow. It was 'who's looking after that child?' (H1, CC2)

The curriculum planning for 2-year-old children is othered to the whole nursery during weekly meetings. Often left as the last item for discussion and considered as not as significant (or 
'interesting') to the 3-4 year-olds: 'No matter how much I talked to and tried to do the planning, we ended up planning separately, as in all of the nursery and the 2-year-olds' (H1, CC2).

A disciplinary effect of the nappy-changing routines is the pressure for children to be 'toilet-trained'. Practitioners often ask parents of new children if their child is in nappies and if their child is showing signs that they are ready for training. Which, in a way, suggests to parents that toilet-training is an aspirational form of 'readiness'. Children are spoken of and classified in terms of 'toilet-trained' or 'not toilet-trained', as this extract from $\mathrm{H} 6$ shows:

You have staff saying, you know, they shouldn't be in nappies ...they should be toilet trained. They should be doing this or that. Why are they doing that? And you think, well, what's gone in that child's life for them to be like that? And people don't necessarily think ... But it's about having expectations. ( $\mathrm{H6}, \mathrm{CC} 2)$

Thus, toilet-training is spoken in terms of readiness and expectations, which sets in place new norms when children reach a certain age or when 2-year-olds attend FNP. Practitioners feel nappy-changing has taken vital disproportionate time away from the nursery and from their role as 'key persons', 'there is a lot more nappies ... you know they've taken over the nursery'.

\section{Reconfiguring established ways of working}

Most of CC2's practitioners are experienced in working with 3 to 4 year-olds and expressed resounding unease at the introduction of FNP. Here, a deputy head describes her staff's initial reaction in 2013:

People were absolutely horrified. And people were saying 'l've never worked with 2-year-olds. What do I do?' And I found that so hard to understand ... It's not looking necessarily about the chronological age of that child. It was like 2-year-olds were these alien beings. ... Why is it scaring you so much to do that with a 2-year-old? (H3, CC2)

H3's perception of children under-five as a homogeneous group is also reflected in the senior teacher's decision to implement mixed-age groupings, 'It was a really hard decision, but I decided that [children] should all be together ... Staff weren't happy about it at all. They felt that those two-year-olds should have been downstairs' (H2, CC2). Some practitioners felt 'overwhelmed' and struggled with the regime of transiting to new and different ways of working with 2-year-olds. Indeed, some practitioners 
describe the realities of working with 2-year-olds as 'a steep learning curve' and struggled to grapple with new expectations of behaviour for younger children:

All of my experience has been with the 3-5s. So I didn't really know what to expect ... it was a little bit tricky, managing the dynamics of the two groups together ... And kind of be overseeing ... apprehensive about what they could manage and how much support they would need. (H5, CC2)

I'm not even sure I understand 2-year-olds ... I don't know if it's because l've worked so long with the older group that my expectations are kind of so set in ... for me I still feel like l'm learning about them still and what to expect and what's sort of normal behaviour for $2 s$... I'm so used to 3-4s. $(H 7, C C 2)$

H8's frustration with the open mixed-age plan is evident in the tension she feels between settling routines and focusing activities for children of different ages. She speaks of the need to 'contain' 2year-olds, what Foucault (1991, p. 142) calls 'enclosure' to 'neutralise the inconveniences'.

If you had a 2-year-olds room, they were contained. You had these ten children and these two practitioners, and you can provide for those children. But on [main] nursery floor, you're providing for 2year-olds, but you're also doing the other things for 3-year-olds. You're doing the focusing. You're settling new children. (H8, CC2)

Governmentality includes 'the way in which the conduct of individuals or groups might be directed' (Foucault, 1982, p. 790), even if it means conducting (normalising) ways of working that seem contradictory to practitioners' training and knowledge of the EYFS. They are constantly worried and feel uneasy that they are not available to settle and form relationships with their new 2-year-olds at the crucial start of the term and importantly, to be the regular person changing their key children's nappies. It is highly problematic when practitioners speak in terms of 'making life easier' where 'an ideal situation' denotes segregating groups and excluding younger children from learning and exploring in a shared larger physical space. Similar to the wider dichotomy that reflects split rationality in 'childcare' and 'education', practitioners too seem to think in set normative ways when it comes to the learning and care of children within their settings.

\section{Conclusion}

Using Foucault's approach to governmentality, this article has examined how the policy of FNP reconfigures early years settings as spaces for new modes of governing. The focus of analysis has 
been to shed light on specific processes of policy within context - specifically, the reshaping and reconfiguring of everyday spaces through framing FNP as a mobile technology of government. Ong's (2007) idea of space as assemblage highlighted firstly, how situated practices and rationalities crystallised conditions of possibility for new ways of working and being with children, and secondly, how situated technologies responded and adapted to new problems and shaped solutions. Three inter-related themes are generated from the data following this approach: dividing spaces through split rationality, dividing practices through othering and reconfiguration of established ways of working.

The first theme relates to everyday routines and practices in which practitioners' pedagogical preferences classify and organise through split rationality to ages and stages. From this perspective, practitioners re-enact and reinforce the wider binary in both government and public psyches between 'childcare' as care services and 'early education' as a universal entitlement. Secondly, the practitioners' selves are self-regulated by a form of 'developmentality' (Fendler, 2001) in which practitioners' conducts are governed through the normalising effects of their professional training, governmental policies and the curriculum of EYFS. An unintended consequence of notions of normality inhabited within sites established for 3 to 4 -year-old is the othering of care for younger children. The influence of othering is perceived in how practitioners spoke of younger children's needs, the tension in nappy changing narratives, the curriculum planning and the professional identities between FNP from 3 to 4-year-olds practitioners. The third theme focuses on how FNP reshapes and reconfigures spaces that were established for 3-4-year-olds. The roles of practitioners are reworked as they struggle to transit to new and different ways of working with 2-year-olds. The three cases demonstrate how policy-driven technologies re-interpret and reinforce the EYFS in narrow and alternative ways by making a set of practices possible - policy as practice and engendering new pedagogical relationships. This article argues that context-bound policy work needs to understand and engage with the complexities and messiness of what is happening within early years settings when implementing policy and provision. The critical question for researchers and practitioners is in challenging rather than reinforcing normalising regimes, particularly the technological effects on young children in ECEC settings. 
I am very grateful to Professor Elizabeth Wood for her insights and helpful comments in formulating the arguments for this paper. My thanks to two anonymous reviewers for their useful comments.

\author{
References
}

Ball, S. J., Maguire, M., \& Braun, A. (2012). How schools do policy : policy enactments in secondary schools. Oxon: Routledge.

Braun, V., \& Clarke, V. (2006). Using thematic analysis in psychology. Qualitative Research in Psychology, 3(2), 77-101.

Dahlberg, G., Moss, P., \& Pence, A. (2007). Beyond Quality in Early Childhood Education and CareLanguages of Evaluation (Second ed.). Oxon: Routledge.

DCSF. (2007). The Children's Plan: Building Brighter Futures. Norwich: TSO.

DCSF. (2009). Next Steps for Early Learning and Childcare: Building on the 10-Year Strategy. London: Department for Children, Schools and Families.

Dean, M. (2010). Governmentality: Power and Rule in Modern Society (2nd ed.). London: Sage.

DfE. (2013a). More Affordable Childcare. London: Department for Education.

DfE. (2013b). More Great Childcare: Raising Quality and Giving Parents More Choice. London: Department for Education.

DfE. (2017). Statutory framework for the early years foundation stage: Setting the standards for learning, development and care for children from birth to five. London: DfE.

DfE. (2019). Provision for children under 5 years of age in England, January 2019. Darlington: Children and Early Years Statistics Retrieved from https://assets.publishing.service.gov.uk/government/uploads/system/uploads/attachment data /file/811683/Provision for children under 52019 - text.pdf.

DfEE. (1998). Meeting the Childcare Challenge. London: HMSO.

DfES. (2002). Birth-to-Matters: A Framework to Support Children in their Earliest Years London: DfES.

DfES. (2004). Choice for parents, the best start for children: a ten year strategy for childcare. Norwich: The Stationery Office.

DfES. (2007). Early Years Foundation Stage. Nottingham: DfES.

DH. (2004). National Service Framework for Children, Young People and Maternity Services. London: DH Publications.

DH. (2011). Supporting Families in the Foundation Years. Retrieved from https://www.gov.uk/government/publications/supporting-families-in-the-foundation-years.

Dunne, L. (2009). Discourses of Inclusion: A Critique. Power and Education, 1(1), 42-56.

Education, E. (2012). Development Matters. London: Early Education Retrieved from https://www.earlyeducation.org.uk/sites/default/files/Development\%20Matters\%20in\%20the\%20Early\%20Years \%20Foundation\%20Stage\%20-\%20FINAL.pdf.

Fendler, L. (2001). Educating Flexible Souls: The construction of subjectivity through developmentality and interaction. In K. Hultqvist \& G. Dahlberg (Eds.), Governing the Child in the New Millennium. London: RoutledgeFalmer.

Field, F. (2010). The Foundation Years: preventing poor children becoming poor adults. London: Her Majesty's Government.

Foucault, M. (1982). The Subject and Power. In H. L. Dreyfus \& P. Rabinow (Eds.), Michel Foucault: Beyond Structuralism and Hermeneutics. Chicago: University Chicago Press.

Foucault, M. (1988). Technologies of the self : a seminar with Michel Foucault. London: Tavistock.

Foucault, M. (1991). Discipline and Punish (A. Sheridan, Trans.). London: Penguin Books.

Georgeson, J., Campbell-Barr, V., Mathers, S., Boag-Munroe, G., Parker-Rees, R., \& Caruso, F. (2014). Two-year-olds in England: an exploratory study. TACTYC Retrieved from http://tactyc.org.uk/research/.

Gibb, J., Jelicic, H., \& La Valle, I. (2011). Rolling out free early education for disadvantaged two year olds: an implementation study for local authorities and providers. (Research Report DFERR131). London: NCB Research Centre, National Centre for Social Research. 
Giroux, H. A. (2001). Theory and resistance in education : towards a pedagogy for the opposition (Rev. and expanded ed. ed.). Westport: Bergin \& Garvey.

Gordon, C. (1991). Governmentality Rationality: An Introduction. In G. Burchell, C. Gordon, \& P. Miller (Eds.), The Foucault Effect: Studies in Governmentality. Chicago: University of Chicago Press.

Hunkin, E. (2016). Deploying Foucauldian genealogy: Critiquing 'quality' reform in early childhood policy in Australia. Power and Education, 8(1), 35-53.

Lee, S. F. (2019). Governing 'disadvantage' through readiness: A Foucauldian policy genealogy of funded nursery places for two-year-olds. Contemporary Issues in Early Childhood.

Lemke, T. (2001). 'The birth of bio-politics': Michel Foucault's lecture at the Collège de France on neoliberal governmentality. Economy and Society, 30(2), 190-207.

Lemke, T. (2002). Foucault, Governmentality, and Critique. Rethinking Marxism, 14(3), 49-64.

Lemke, T. (2012). Foucault, governmentality, and critique. Boulder: Paradigm Publishers.

Lewis, J., \& West, A. (2017). Early Childhood Education and Care in England under Austerity. Journal of Social Policy, 46(2), 331-348.

Lloyd, E., \& Penn, H. (2014). Childcare markets in an age of austerity. European Early Childhood Education Research Journal, 22(3), 386-396.

MacNaughton, G. (2005). Doing Foucault in early childhood studies : applying poststructural ideas. London: Routledge.

Maisey, R., Speight, S., Marsh, V., \& Philo, D. (2013). The Early Education Pilot for Two Year Old Children: Age Five Follow-up. London: NatCen Social Research.

Mathers, S., Eisenstadt, N., Sylva, K., Soukakou, E., \& Ereky-Stevens, K. (2014). Sound Foundations. A Review of the Research Evidence on Quality of Early Childhood Education and Care for Children Under Three. Oxford: University of Oxford.

Moss, P. (2010). The democratic and reflective professional. Rethinking and reforming the early years workforce. In C. Cable, G. Goodliff, \& L. Miller (Eds.), Supporting children's learning in the early years (2nd ed.). London: Routledge.

Moss, P. (2014a). Early childhood policy in England 1997-2013: anatomy of a missed opportunity. International Journal of Early Years Education, 22(4), 346-358.

Moss, P. (2014b). Transformative Change and Real Utopias in Early Childhood Education: A story of democracy, experimentation and potentiality. Oxon: Routledge.

Moss, P. (2017). Power and Resistance in Early Childhood Education: From Dominant Discourse to Democratic Experimentalism. Journal of Pedagogy, 8(1), 11-32.

Moss, P., \& Urban, M. (2017). The Organisation for Economic Co-operation and Development's International Early Learning Study: What happened next. Contemporary Issues in Early Childhood, 18(2), 250-258.

Ong, A. (2006). Neoliberalism as Exception: Mutations in Citizenship and Sovereignty. Durham N.C., U.S.A.: Duke University Press.

Ong, A. (2007). Neoliberalism as a mobile technology. Transactions of the Institute of British Geographers, 32(1), 3-8.

Osgood, J. (2006a). Deconstructing Professionalism in Early Childhood Education: Resisting the Regulatory Gaze. Contemporary Issues in Early Childhood, 7(1), 5-14.

Osgood, J. (2006b). Professionalism and performativity: the feminist challenge facing early years practitioners. Early Years, 26(2), 187-199.

Osgood, J. (2010). Reconstructing professionalism in ECEC: the case for the 'critically reflective emotional professional'. Early Years, 30(2), 119-133.

Osgood, J. (2012). Narratives from the nursery: negotiating professional identities in early childhood. Oxon: Routledge.

QCA. (2000). Curriculum Guidance for the Foundation Stage. London: The Qualifications and Curriculum Authority.

Rose, N. (1993). Government, authority and expertise in advanced liberalism. Economy and Society, 22(3), 283-299.

Rose, N. (1999a). Governing the soul : the shaping of the private self (2nd ed. ed.). London: London : Free Association.

Rose, N. (1999b). Powers of Freedom : Reframing Political Thought: Cambridge : Cambridge University Press.

Rose, N., O'Malley, P., \& Valverde, M. (2006). Governmentality. Annual Review of Law and Social Science, 2(1), 83-104.

Sahlberg, P. (2011). The Fourth Way of Finland. Journal of Educational Change, 12(2), 173-185. doi:http://dx.doi.org/10.1007/s10833-011-9157-y 
Smith, R., Purdon, S., Schneider, V., La Valle, I., Wollny, I., Owen, R., . . Lloyd, E. (2009). Early Education Pilot for Two Year Old Children. (DCSF Research Report No. DCSF-RR134). London: DCSF/NCSR.

Speight, S., Smith, R., Coshall, C., \& Lloyd, E. (2010). Towards universal early years provision: analysis of take-up by disadvantaged families from recent annual childcare surveys. (DFERB066). National Centre for Social Research.

Urban, M. (2017). We Need Meaningful, Systemic Evaluation, Not a Preschool PISA. Global Education Review, 4(2), 25-39.

Wood, E. (2017). Broad Policy Issues. BERA-TACTYC Early Childhood Research Review 2003-2017. Retrieved from https://www.bera.ac.uk/project/bera-tactyc-early-childhood-research-review$\underline{2003-2017}$

\section{Notes}

${ }^{\mathrm{i}}$ http://www.seed.natcen.ac.uk/reports.aspx

${ }^{i i}$ https://consult.education.gov.uk/early-years-quality-outcomes/early-years-foundation-stagereforms/supporting_documents/EYFS\%20reforms\%20consultation.pdf

iii https://www.oecd.org/pisa/aboutpisa/pisa-participants.htm

${ }^{\text {iv }}$ https://www.gov.uk/government/statistics/schools-pupils-and-their-characteristics-january-2017 